\title{
GPC5 wt Allele
}

National Cancer Institute

\section{Source}

National Cancer Institute. GPC5 wt Allele. NCI Thesaurus. Code C88171.

Human GPC5 wild-type allele is located in the vicinity of $13 q 32$ and is approximately 2671 $\mathrm{kb}$ in length. This allele, which encodes glypican- 5 protein, is involved in the mediation of cellular interactions with the extracellular environment. A genetic variation may be associated with increased susceptibility to lung cancer in non-smokers. 